\title{
EDITORIAL
}

\section{LA REVISTA CHILENA DE DERECHO EN EL BICENTENARIO}

En vísperas del Bicentenario de nuestro Chile republicano, numerosas instituciones, cuerpos intermedios de la sociedad, personas y grupos desarrollan estudios, reflexiones e incluso celebraciones de este hito en la historia del país.

Los hechos ocurridos el presente año (terremoto de febrero, interpretación de la encuesta CASEN como retroceso en la lucha contra la pobreza, recrudecimiento de los delitos violentos y afortunadamente hallados con vida pero la situación de los treinta y tres mineros de la mina San José aún sin rescatar al cerrar este número, nos hacen mirar el Bicentenario con humildad y sin triunfalismos.

Es verdad que Chile ha progresado y se ha desarrollado de muchos modos: somos un país internacionalmente prestigiado y confiable, nuestra Carta Fundamental es una fuente genuina de consenso social, hemos modernizado procedimientos y controles en torno a la gestión de los órganos del Estado, incursionamos en los avances científicos y tecnológicos, ha crecido nuestra conciencia en torno a los derechos fundamentales de las personas y a valores transversales como la protección del medio ambiente y la de nuestra identidad cultural; pero también es cierto que nos resta mucho para decir que efectivamente reinan en nuestra patria la certeza y seguridad jurídicas, la equidad y la responsabilidad.

En efecto, cada una de las situaciones que de un modo u otro conmocionan a Chile, decodificadas adecuadamente, nos dan un mensaje acerca de temáticas y materias en las cuales el Derecho chileno tiene algo que decir y debe hacerlo. En algunos casos hay ausencia de normas adecuadas y actualizadas, en otros, la ejecución de estas presenta falencias o poca acusiosidad, y, por último, faltan dinámicas y oportunas interpretaciones.

Sin embargo, los "pendientes", más que deméritos, son necesariamente objetivos que el Derecho ha de darse en los próximos años, cuya identificación y reconocimiento son fundamentales para aportar las debidas soluciones, priorizando lo urgente y lo importante respecto de aquello que puede esperar.

Frente a un Derecho así demandado y escrutado, que sin duda constituye una parte relevante de las herramientas sociales para hacer frente a las problemáticas y conflictos sobrevinientes y complejos, nuestra Revista se plantea como un instrumento que aspira no solo a seguir siendo una fuente constante de consulta y de revisión por nuestro mundo jurídico, sino una vía para impulsar y promocionar el estudio, la investigación y el debate en tres tipos de materias: aquellas cuya literatura nacional es escasa, pese a representar instancias normativas y doctrinarias de gran valor; las temáticas de frontera, que demandan de la ciencia jurídica la relación y la interdisciplina con otras áreas del conocimiento, enriqueciendo así las fuentes de decisión y los conceptos y elementos de 
juicio con que han de contar los reguladores, legisladores y sentenciadores; $y$, finalmente, el análisis de las situaciones o casos que se identifican con conflictos de derechos o con situaciones que, por lo novedosas y sobrevinientes, requieren un mayor esfuerzo interpretativo para su solución.

Ya en este número se abordan algunas de estas temáticas tanto en nuestros estudios como comentarios de jurisprudencia, y para recordar el camino andado de la mano con la determinación de la ruta hacia el futuro, hemos pedido al coordinador de nuestra Revista, quien a su vez es novel historiador -dada su juventud, no su inexperiencia-, encabezar la sección de ensayos y crónicas con una reflexión jurídica acerca de estos doscientos años de vida independiente.

Felicitamos y nos sumamos con este aporte académico, así, a quienes, desde variadas instancias y sensibilidades, trabajan para seguir haciendo de nuestra patria un Estado de Derecho, en que la justicia, la dignidad de las personas y el deber de servicio hacia ella se materialicen en el día a día y no solo en una emocionante fiesta de septiembre. 